\title{
The Decoding of Traffic Signs by Motorcycle Riders in Jakarta Indonesia
}

\author{
Bambang Winarso \\ University of Prof. Dr. Moestopo (Beragama), Jalan Hang Lekir, Jakarta, Indonesia \\ E-mail: bbwinarso@dsn.moestopo.ac.id
}

\begin{abstract}
Should the rapid growth of motor vehicles and inhabitants goes unanticipated, it is certain that the motor vehicles pacing in JABODETABEK area will significantly decelerate. The problem of clogging in Jakarta is not only due to the ever-increasing number of motor vehicles and minimum development of streets but also to the behavior of road users. The behavior of road users is vital in solving the problems in transportation such as clogging or traffic safety like the circumstances in Jakarta today. This study aims at analyzing and understanding the occurrence of disorderliness/indiscipline phenomenon in road traffic, in particular, the one related to ignorance to the meaning of traffic signs, road markings, and traffic signal emitting devices perceived from the social scope. This study employs qualitative method and is limited to specific road segments in Jakarta Megalopolis Area, in particular the ones passed by the author, including Jakarta, Southern Tangerang, and Depok City areas. From the discoveries, the violation and ignorance to the meaning of traffic signs, road markings, and traffic signal emitting devices are stimulated by internal and external factors. The motorcycle riders are inclined to ignore the meaning of traffic signs, road markings, and traffic signal emitting devices due to conditions such as the non-existence of sanction unless when there is police inspection. The role and presence of traffic and transportation officer at the intersection or road crossing do not seem optimum.
\end{abstract}

Keywords — transportation; traffic; policy; vehicle; apparatus

\section{INTRODUCTION}

Jakarta transportation infrastructure development has promoted urban sprawl in Jakarta's peripheries [1]. In 2014, the number of four-wheeled motor vehicle is amounted to 3.04 million units or 669 units a day, while two-wheeler motor vehicle 6.21 million units or 1,535 units a day (DKI Jakarta Transportation Department, 2014; the data on the increase in the number of DKI Jakarta motor vehicle; data.jakarta.go.id). Those numbers are kept increasing inline with the growth of inhabitants of Jakarta Megalopolis, including Jakarta, Bogor, Depok, Tangerang, South Tangerang and Bekasi (Jabodetabek). In truth, this condition challenges the authority to provide adequate facilities for the inhabitants of Jakarta Megalopolis. Maksum [2] states that Jakarta has developed rapidly. The number of her inhabitants has reached the criteria number of megacities proposed by Prud'Homme of no less than 8 million. Meanwhile, the facilities do not match those found in megacities in modern countries. In truth, from the output, this city is signified by how harsh and unpleasant it is to live in it.

From Demography and Civil Registry Agency of DKI Jakarta, the Regional Regulation (Perda) concerning City Planning stipulates that up until 2030 the city inhabitant number will be restricted to only 12.5 million. However, the reality shows that in 2011 the number of Jakarta inhabitants has reached 9.6 million; while 2.5 million others come every day from the peripheries to do their activities there. They come from every direction using various mode of transportation. Thus, during the day, the population of Jakarta can reach the number of 12.1 million. Meanwhile, the data from Master Plan of Transportation of Jabodetabek (MPTJ) for Jabodetabek Megalopolis area show that the number of inhabitants for the entire year has reached 31.68 million with a growth rate of $1.03 \%$ in Jakarta and $2.8 \%$ in the peripheries. If the rapid growth of motor vehicle and inhabitant goes unanticipated, it is certain that the pace of motor vehicles in Jabodetabek area will be significantly reduced. The Master Plan for Transportation of Jabodetabek shows that, if not handled well, in the morning, network performance of Jabodetabek area will experience a pace reduction in non-highways up to $6.32 \mathrm{~km} / \mathrm{h}$ in 2030, a decrease from 2012 which reached $22.51 \mathrm{~km} / \mathrm{h}$. Meanwhile, it is estimated that the pace of vehicle on highways in 2030 shall decline to $9.44 \mathrm{~km} / \mathrm{h}$ or a decrease from 2012 which reached $34.03 \mathrm{~km} / \mathrm{h}$.

The matter of clogging in Jakarta is not only caused by the increasing number of motor vehicles and the minimum development of road segments but also for the mannerism of road users. According to Transportation Study Institute 
(Instran), road users' behavior added $20 \%$ of clogging. This condition gets worse due to policemen irresoluteness to act against mischievous driving by public transportation workers. Careless behavior such as stopping at random spots and also the inadequate condition of public transportation indeed has the logical consequence of worsening the clogging problem in Jakarta.

Road users' behavior is vital in overcoming transportation problems such as clogging and traffic safety. Nejad et al. [3] believed human factor as the most important factor in driving violation both from social or cultural aspects. This is supported by other researchers such as the one by Alhindi and Albawardy [4] that according to several studies the primary cause of road crashes is the human element $(80 \%)$. This shows that motor vehicle users' behavior seriously determines transportation safety.

Bad understanding of traffic signs will evoke the emergence of various problems such as clogging. Razzak and Hassan [5], Zhang and Chan [6] describe the similar picture that for developing countries, unsatisfactory comprehension is a common problem for drivers. Razzak and Hassan [5] in their research in Dhaka and Bangladesh find that drivers' knowledge or understanding is vital in responding to traffic signs. Zhang and Chan [6] states that traffic signs are effective only when users clearly understand their meaning. Generally, drivers with higher educational background performed better.

The condition depicted above is similar to the one met by Jakarta Megalopolis. Concerning the situation and condition of traffic in Jakarta megalopolis area, the researcher perceives a phenomenon of ignorance of communication messages between traffic organizer agency through traffic signs, road markings, as well as traffic signal emitting devices, and road users, namely automobile and motorcycle drivers.

In this context, the researcher perceives government policies in transportation sector over time emphasize more on the increase of automotive products and their sales. The number of motor vehicles increases uncontrollably. On the other hand, this condition is not compensated with the comprehensive transportation system, including the availability of roads to contain the vast number of motor vehicles, adequate rules, and law enforcement. Moreover, everyday changes of people's lifestyle as a result of advancement in information and communication technology and other technology also affect the phenomenon studied here.

Road users' awareness of the existing rule and order is at minimum, the demand of time also becomes a factor affecting violation of traffic signs, road markings, and traffic signals devices. Similarly, the degraded image and power of the officer contribute to the phenomenon studied. The faded or disappeared road markings add more to the loss of meaning of the message that road users should notice.

The aim of this study is to analyze and understand the emergence of the phenomenon of disorderliness/indiscipline in street traffic, primarily the one related to the ignorance of meaning of traffic signs, road markings, and traffic signal emitting devices observed from social aspect, particularly related to Symbolic Interaction Theory of George Herbert Mead, Social Exchange Theory of John Thibaut and Harold
Kelley, and Phenomenology Theory of Edmund Husserl and Alfred Schutz and other phenomenology figures, as well as other relevant theories. In addition, it also observes the object of the study from the aspect of the implementation of stipulation, namely Traffic Law No. 22 Year 2009.

The goal of this study is to discover the matters evoking motorcycle riders' inclination to violate traffic rules, primarily at the intersection and the role of road traffic and transportation officer in upholding the law. Another goal is to discover how motorcycle riders understand the message conveyed through traffic signs, road markings, and traffic signal emitting devices.

The rest of this paper is organized as follow. Section II describes methodology and data used in this study. Section III presents results and following by discussion. Finally, the conclusion of this work is presented in Section IV.

\section{MATERIAL AND METHOD}

This section presents the method and the data used.

\section{A. Proposed Method}

This study employs qualitative method with the descriptive interpretative approach. The data are collected through observation of the object of the study and deep interview supported by literature study of various sources.

This study focuses on occurring social phenomenon, including the aspects of the place, actor, and activity which interact synergistically. Therefore, this qualitative study depicts the occurrence of a phenomenon such as the change of people behavior when on the street and the inclinations. In connection, data collected from field observation is quite dominant since the actions of motorcycle riders in particular and public transportation drivers, in general, can be observed every day by all including the author. Apart from field observation, the author also conducts interviews with several informants, namely motorcycle riders who go to work on their motorcycle every day, motorcycle taxi riders passing the lines where the author conducts the study and officers having duties at the study location.

An intensive study was conducted during August 2013 and February 2014. The author then limited the study to specific road segments in Jakarta Megalopolis, in particular, South Jakarta, South Tangerang and Depok City. From general observation, the phenomenon of disorderliness and violation of traffic signs, road markings and traffic signal emitting devices (traffic lights) in Jakarta and the peripheries can be regarded as even and almost identical.

\section{B. Dataset}

From 2010 data, the number of intersection (three or four ways) in Jakarta amounts to 3,000. There are 530 locations of traffic lights. Also, there are 1,300 bus stops, 151 Transjakarta Corridor I - X stops, and 51 U-turn. This study, in particular, observes only some of 3,000 intersections in Jakarta. However, in general, it can be assured that the condition and situation are even or almost identical to the ones the author conducting study in.

\section{Rudimentary}

1) Symbolic Interaction Theory of George Herbert Mead: Mead's theory is heavily influenced by other thinkers. 
According to Mead, people has the capability of interpreting symbols, people will act based on the meaning of the symbol accepted at certain situation. The symbol is an arbitrary label or representation of a phenomenon. Mead's theory states that there is a connection between symbols and interactions occurred [7]. The author finds this theory appropriate for analyzing and understanding the behavior of road users, in particular, two-wheeler (motorcycle) riders. Mead identifies four foundations and stages of related actions which are an organic unity or have dialectic connections, namely impulse, perception, manipulation, and consumption.

The road users belong to instant community experience perception process. In perception stage, actor scrutinizes and reacts to stimulation, related to impulse. Perception involves the stimulation accepted and the mental image created. The actor does not spontaneously respond to external stimulation but thinking it over for a while and assessing it through mental vision. A human does not only submit to external stimulation, they are also actively choosing the stimulation characteristics and choosing among a group of stimulations [8]. Each person's perception over one or more stimulations can be similar or varied and can evoke similar reaction or action, which in the end will form a cultural or identity group. Mulyana [9] believes that perception is the core of communication while interpretation is the core of perception which is identical to decoding in the communication process.

Mulyana [9] quotes the opinion of Sereno and Bodaken, and the opinion of Pearson and Nelson that perception comprises of three activities, namely selection, organization, and interpretation. What defined as selection actually includes sensation and attention, while the organization is attached to interpretation, which can be defined as putting stimulation with other stimulation so as to become a meaningful entirety. There is no clear boundary between each stage on when they begin or end. Mulyana [10] believes that the event happens almost simultaneously.

Ralph LaRossa and Donald C.Reitzes [11] assume that Symbolic Interaction Theory reflects three central themes, namely: the importance of meanings for human behavior, the importance of the self-concept and the relationship between individual and society (West \& Turner, 2007: 96). Symbolic Interaction Theory perceives that individual constructs meaning through communication process since meaning is not based on anything. It takes inter-human interpretation construction to create meaning. According to this theory, the goal of interaction is to share meaning. How do those riding or driving truly share the meaning of traffic signs? In this context, LaRossa and Reitzes quote three assumption of Blummer [11] about meaning, namely that Human act toward others on the basis of the meanings those others have for them; Meaning is created in the interaction between people; Meaning is modified through an interpretive process.

2) Social Exchange Theory of John Thibaut and Harold Kelley: Social Exchange Theory perceives that someone or an individual voluntarily enter and be in a relationship only if it is calculated sufficiently for his needs, including profit and cost. Thibaut and Kelley frequently call Social Exchange Theory as Theory of Interdependence, while Sabatelli and Shehan [12] suggest social exchange to be approached from market segment metaphor where everyone act out of personal orientation of taking benefit. However,
Michale Roloff believes that social exchange is closely related to the argument that inter-individual relation is an extension of the needs of each party [13].

In this study, the author prefers the theory of Thibaut and Kelley in discussing the study material. Social Exchange Theory is constructed under the assumption of two matters, namely human nature and the nature of the relationship. In its assumption of human nature, Social Exchange Theory believes that human pursues reward and eludes punishment, which is consistent to Roloff conceptualization of stimulant reduction. This approach assumes that someone's behavior or action is stimulated by internal stimulant mechanism motive.

The second assumption is that humans are rational. Social Exchange Theory suggests that in the scarcity of information, human will calculate the cost and reward of the present situation, which drives human to act accordingly. Human will rationally think of choosing between available choices.

The third assumption is that the standards that humans use to evaluate costs and rewards vary over time and from person to person. Theory must evaluate available differences. There is no genuine standard to be applied to everyone on what the cost is and what the income (reward) is. Human, in general, will try to minimize expenditure and maximize income. On this assumption of the nature of relationships, this theory states that there is interdependence in a relationship and connected life is a process.

3) Phenomenology of Edmund Husserl and Alfred Schutz: Phenomenology is proposed by Edmund Husserl and Alfred Schutz or other phenomenology experts such as Martin Heidegger, Jean-Paul Sartre, Maurice Marleau-Ponty, Max Scheler, Max Weber, and Peter Berger. Phenomenology is a study on the life and social condition of a human community which describes social reality. Husserl states that a phenomenon is an intentional object of the subjective conscious action. Phenomenology classifies each conscious action taken, simultaneously predicts next actions. The source of it is how someone explains the object in experience. Therefore, phenomenology is also comprehended as a study of meaning in a more extensive sense or of the knowledge comes from consciousness in daily life [14]. The meaning of phenomenon, in general, is a certain condition observed continuously or repetitively. Phenomenon can occur everywhere, both in universal occurrences and human and animal behavior levels.

Husserl believes that the primary principle of philosophical background is consciousness. Thus, what continuously appears can be called a phenomenon. The occurrence of disorderliness or indiscipline of traffic on the road and intersection is a phenomenon that can be studied as a new culture. A culture of gathering and having consensus to do something and it is only temporary, although it can occur every time everywhere.

4) Legislations on Traffic and Road Facilities: The matter of road traffic and transport is regulated in Law Number 22 Year 2009 [15], signed by President Susilo Bambang Yudhoyono on 22 June 2009, enacted on 22 June 2009 and effective since the date of the signing. By the effectiveness of Law Number 22 Year 2009, the old regulation, Law Number 14 Year 1992 on Road traffic and 
transport (State Gazette of the Republic of Indonesia Year 1992 Number 49, Addendum State Gazette of Republic of Indonesia Number 3480) is declared ineffective. Law Number 14 Year 1992 was the substitution of Law Number 3 Year 1965 on Road traffic and transport (State Gazette Year 1965 Number 25, Addendum State Gazette Number 2742).

The role of road traffic and transport is vital since it is related to the necessity of society. Every day, members of society need and use the road, use transportation mode for their activities both in their job, business, and school, visit family house, recreation, and others. Road traffic and transport are also the backbone of society and national economies, both in micro and macro scale. It is due to the vitality of road traffic and transport that it is regulated in a national transportation system in Law Number 22 Year 2009.

One important matter related to this study is Article 25 Paragraph (1) of Law Number 22 Year 2009 as follows:

"Every Road used for public Traffic must be equipped with Road facilities, namely:

- Traffic Signs;

- Road Markings;

- Traffic Signal Emitting Devices;

- Street Lamps;

- Road user controlling and safety device;

- road monitoring and safety device;

- facilities for bike, Pedestrian, and handicapped people, and

- h. supporting facilities for Road Traffic and Transport activity on and outside the road."

In addition, Traffic Procedures are regulated in Part Four Paragraph I on Order and Safety, Clause 105 and 106 [16]. Clause 105 regulates that:

Anyone using the road is compelled to:

- behave properly; and/or

- prevent things that can obstruct, endanger Security and Safety of Road Traffic and Transport, or that can damage the Road.

While clause 106 regulates that:

(1) Every person driving Motor Vehicle on the Road must drive in proper and full of concentration way.

(2) Every person driving Motor Vehicle on the Road must prioritize the safety of Pedestrian and bicyclist.

(3) Every person driving Motor Vehicle on the Road must obey stipulation on technical and suitability requirements.

(4) Every person driving Motor Vehicle on the Road must obey the stipulations:

- order or prohibition signs;

- Road Markings;

- Traffic Signal Emitting Devices;

- Traffic movement;

- stop and Park;

- sound and light warnings;

- minimum or maximum speed; and/or

- procedure for connecting and attaching to other Vehicle.

(5) ........ and so on... up to clause (9).

Law number 22 Year 2009 does not clarify the meaning of traffic signs, road markings, and traffic signals emitting devices. Stipulation for Road facilities as is mentioned in
Article 25 Law Number 22 Year 2009 on Road Traffic and Transport should be regulated through Governmental Decree. However, up to now, there is no Governmental Decree on Traffic as is ordered in Article 25 of Law Number 22 Year 2009.

The meaning of traffic signs, road markings, and traffic signal emitting devices can be taken from previous Traffic Law, namely Law Number 14 Year 1992, as follows: The meaning of signs are one of road facilities in certain form containing symbol, letter, number, sentence and/or combination of them, used to give warning, order and guidance for road user. Meanwhile, the meaning of road markings are a sign on or over road surface including devices or signs in the form of a horizontal line, vertical line, diagonal line, and other symbols which function is to direct traffic flow and traffic necessity area.

Traffic signal emitting devices or TSED is a technical device in the form of light signal that can be furnished with sound to warn or arrange traffic of people and/or vehicle at the intersection, crossing or street flow. In the Decree of Directorate General of Land Transport Number: 273/HK.105/DJRD/ 96 on Technical Guidance of Traffic Management at Independent Intersection with Traffic Signal Emitting Device, referring to Decree of Minister of Transportation Number: 62 Year 1993 on Traffic Signal Emitting Devices, stipulates that Intersection is a gathering or branching of roads, both as a section or not a section; Traffic Signal Emitting Device (TSED) is technical devices using light signal to organize people and/or vehicle at the intersection or road segments. Filter lamp is an addition lamp on TSED with an arrow to show vehicle movement.

Next, it is mentioned that Intersection Entry further (IE) is the area at intersection used for vehicle queue before passing stop line. TSED has three colors to organize vehicles, namely red, yellow and green for three lamps. Two color lamps are to organize vehicle and/or pedestrian using red and green colors. Single color lamps are for warning, using red or yellow colors. The function of TSD is to: organize the utilizing of intersection space, enhance traffic flow order, enhance intersection capacity, and reduce accident in the vertical direction. For left turn traffic at the intersection, organized by TSD or not, in principle vehicles may directly make a left turn. If left turn traffic constantly disturbs the entire traffic, a filtered lamp or an order sign of Turn Left According to the Light can be installed.

The meaning of traffic signs, road markings, and traffic signal emitting devices is a key part of this study since traffic signs, road markings, and traffic signal emitting devices are the signs or symbols to convey certain messages to road users. It means that signs or symbols are made to be obeyed not ignored.

5) Function and Meaning of Road Signs and Markings: Law Number 22 Year 2009 does not specify the meaning of traffic signs, road markings and traffic signal emitting devices. The regulation of road facilities such as mentioned in Article 25 Law Number 22 Year 2009 on Road Traffic and Transportation should be stipulated in a Governmental Decree which up to now has not been materialized. To understand the meaning of those terms, the author refers to an explanation of Article 8 Paragraph (1) of Law Number 14 Year 1992 which has been declared ineffective. According 
to the explanation of the article, the meaning of signs are one of road facilities in certain forms containing symbol, letter, number, sentence and/or combination of them, used to give warning, prohibition, order and guidance to road users. All motor vehicle drivers surely know and understand the meaning of traffic signs, in particular, the ones conveying certain order or prohibition. However, in reality, those signs do not convey any meaning to the motor cycle riders.

Similar to traffic signs violation, road markings are also getting violated. Road markings are signs on or over the surface of the road including devices or signs forming a horizontal line, vertical line, diagonal line and other symbols functioning to direct the flow of traffic and traffic necessity area. Road markings at the intersections are white lines at the end of the road before the intersection, several meters before the traffic light. In certain areas, road markings are made more clearly and there are also some white or yellow lines forming a box connecting the tips of the intersections. If any motorcycle or car enters the box area during red light, the person will be given ticket by the officer.

6) Sanction for Violation of Traffic Signs, Road Markings and traffic signal emitting devices: Law Number 22 Year 2009 on Road Traffic and Transportation explains in Article 287 as follows:

Article 287

- Every person driving Motor Vehicle on the Road violating order or prohibition rules clarified by Traffic Signs as declared in Article 106 Paragraph (4) letter a or Road Markings as intended in Article 106 Paragraph (4) letter b will get punished with maximum 2 (two) months custody or maximum fine of IDR 500,000 (five hundred thousand rupiahs).

- Every person driving Motor Vehicle on the Road violating order or prohibition rule clarified by Traffic lights as intended in Article 106 Paragraph (4) letter c will get punished with maximum 2 (two) months custody or a maximum fine of IDR 500,000 (five hundred thousand rupiahs).

- Every person driving Motor Vehicle on the Road violating traffic movement rule as intended in Article 106 Paragraph (4) letter d or stop and Park procedure as intended in Article 106 Paragraph (4) letter e will get punished with maximum 1 (one) months custody or maximum fine of IDR 250,000 (two hundred fifty thousand rupiahs).

- Every person driving Motor Vehicle on the Road violating regulation on use or primary right of Motor Vehicle using warning device with sound and light as intended in Article 59 Paragraph (4) letter f or Article 134 will get punished with maximum 1 (one) months custody or maximum fine of IDR 250,000 (two hundred fifty thousand rupiahs).

- Every person driving Motor Vehicle on the Road violating the rule of maximum or minimum speed limit as intended in Article 106 Paragraph (4) letter g or Article 115 letter a will get punished with maximum 2 (two) months custody or a maximum fine of IDR 500,000 (five hundred thousand rupiahs).

- Every person driving Motor Vehicle on the Road violating procedure of connecting and attaching to other Vehicle as intended in Article 106 Paragraph (4) letter $\mathrm{h}$ will get punished with maximum 1 (one) months custody or a maximum fine of IDR 250,000 (two hundred fifty thousand rupiahs).

\section{RESULTS AND DISCUSSION}

\section{A. Some Field Discoveries}

The author discovers several dynamics during field data collection. There are many interesting matters to note which become a phenomenon in this study. One case involves an informant, B. P., a private company employee. Every day, including Saturday, the informant goes to and from his home in Sarua, Bojongsari-Depok City to his office in Kebun Jeruk, West Jakarta on his motorcycle. Replying to the author's question on traffic ethics and violation of traffic signs, B. P. says:

"I actually don't like to race. However, when you come to Ciputat area, you will face clogging, not to mention when you reach Pondok Indah. It is like you get carried away by the other motorcycles; you will end up riding at high speed. ... On the matter of traffic signs or road markings violation, it depends on the situation. We are in the same crowd with other motorcycles. So I often have to just follow the one in front of me."

When asked: "Why should you race?" the informant explains:

"It is because I have to be at the office by 8 a.m. If I arrive late, my lunch money will be cut or if it happens a lot, I will get a warrant from the boss." (Interview dated on 20 December 2013, at 6.30 p.m. in Ciputat Mosque, South Tangerang)".

According to the informant, he has worked at an automobile dealer in Kebun Jeruk, West Jakarta, for one year. Previously, he worked at another automobile dealer in Mampang Prapatan. About the behavior of riders at the intersection, he explains:

"At the intersection, I don't really pay attention to road markings, since my focus is on the traffic light. I know what road markings are for, but many of them are unclear. Moreover, since I jostle with other motorcycles, well I have to split lanes between cars with the other motorcycles, and we all want to be at the front... Indeed, we realize that we pass the zebra cross, but the others do the same ... and the officers do nothing. I have even been told to move forward since there are so many motorcycles. Perhaps, it is to reduce the clogging".

"... but once when I passed Radio Dalem, right at the intersection from Gandaria to Radio Dalem, the officer told us, the motorcycles, to back off. However, the motorcycles keep still, it seems they don't want to back off ... If we are at the front and we don't go forward quickly, the others behind us will honk at us, simultaneously cry ... go on, go on ... let alone if there are Metro Mini or Kopaja (small public transportation) behind us. The crew will command us as if they are officers." (Interview dated on 20 December 2013, at 6.30 p.m. in Ciputat Mosque, South Tangerang).

Analyzing the replies of informant B. P., he is forced to race to get to the office on time. Moreover, the situation on the street, in particular at the intersection, prompts him to mimic the behavior of other riders. B. P. also says that he understands the meaning of traffic signs, but when he is on 
the move, he concentrates only on how fast he can get to his destination and races other vehicles, although it means he has to ignore his safety sometimes.

Other case is when the author use the service of motorcycle taxi at Senayan area on the way home and the rain falls down so the author must take shelter in the underpass of Pasar Jumat road. At this location, the author interviews another informant with the initial Her. Her is a private company employee in Jakarta area and he lives in Parung, Bogor. There are several replies to be noted in this interview, among others:

"If we don't take shelter, we will get wet, regardless of raincoat. It is troublesome since I am not in the fit condition that I will catch a cold tomorrow. Well, riding a motorcycle when you catch cold will make it even worse. So, though I will get home late, it is better than catching a cold. ...for me, since the distance from home to office is quite far, let alone if I start from home late, I am forced to race to catch up some time. This road we pass here is known for constant clogging every day. There is no difference between the morning or the afternoon (Interview in early December 2013, about 5.30 p.m.).

Another picture is collected from a motorcycle taxi rider who explains that if he does not race or split lanes he will lose time. He has some customers that he takes to Joglo area in West Jakarta, Warung Buncit in South Jakarta, and even to Depok City. Therefore, at certain times he must stand by at his customer's place around Senayan City in Central Jakarta. In the author's observation, this taxi rider under initial A rides at high speed splits lanes between automobiles, and he does it expertly. When we arrive at the intersection of Pondok Indah-Lebak Bulus, South Jakarta, the author asks him why he exceeds the road markings. He simply replies "it's more convenient this way". If he is at the back, apart from being obstructed by other vehicles, he will miss the traffic light. He says "Everybody does the same".

The next informant is Jk, who lives in South Tangerang. The author interviews him in front of ATM BNI booth in UIN Ciputat. From covert observation, the author gets information about him. His initial is JK, and he says that he works in an office/department around Monas. He lives in a housing complex around Bojongsari, Depok City. He has for a long time go to and fro on his motorcycle. He says that riding a motorcycle has a great risk, tiresome, affected by the weather, and others. However, on the other hand, riding a motorcycle has its own benefit, namely getting to the destination sooner, being able to take a shortcut, being able to split the lanes, and less money spent on gasoline.

On the many violations of traffic signs and traffic light at the intersection, he says:

"...so, what else should I do? That is the situation..., others do the same, and the officers take no action. Sometimes we don't even think of our position since we focus more on the traffic light, ... and the street ahead ... is there any motorcycle from the left or the right direction, or not ... that is all ..." (Interview on 3 January 2014, 07.30 a.m.).

The next informants the author met were two motorcycle transportation riders under the initials $\mathrm{M}$ and Juh who live around the author's home in Pamulang, South Tangerang. M is accustomed to taking the long route, while Juh, just as a common housing complex rider, still hesitates when dealing with the orderliness of the street, whether when he races or splits the lanes. $M$ rides expertly, at high speed but still considerate. When asked during a trip whether he understands the meaning of traffic signs, road markings, and traffic lights, he replies "yes". He seems to try to follow the rules, stays in the left lane, except during overtake, and stays behind zebra cross at the intersection. However, if needed, he does not hesitate to split lanes. Meanwhile, Juh seems to hesitate in a crowded street, and he also shows his trauma for being busted twice during police inspection in Ciputat and Pasar Jumat to Pondok Indah.

Similar to $\mathrm{M}$ are two other motorcycle taxi riders operating in Taman Pamulang circle, South Tangerang. The two informants, Isr and Ra, are used to long route. Similar to other riders, they overtake others, split lanes and ride at high speed but controlled. On the matter of traffic signs, road markings, and traffic lights violation, they say that previously when the number of motorcycles was not as many, people did not violate the rules, including at the intersection. However, it is different now. They also find difficulty in getting passenger since the number of motorcycle transportation is overflowing. Previously, they say, it was a passenger who seeks the motorcycle transportation, and it could take a while. Now, it is the riders who seek for passengers, and it also takes a while, since they have to compete with other riders. Isr who has done his trade for 20 years say that traffic violation often happens since people nowadays do not care of others or of the environment. Now, people are demanded to be fast without minding the risk as long as they get to their destination sooner.

Another informant the author met is a police officer of traffic department who is doing his duty around Pondok Pinang, South Jakarta. He says that the drivers and riders today are difficult to be controlled. On average, they ignore the rules. It seems like some kind of trend, those who do not violate the rules are considered bad driver or a coward.

Another informant is an officer of the transportation department (DLLAJR) at Gandaria area, South Jakarta. He does not seem eager to answer the questions. He says that the matter of traffic violation, be it traffic signs, road markings, and traffic lights is a police matter. He and his colleague only have the duty of assisting in ease the situation on the street, also monitoring cargo vehicles such as pick-up, truck, and others.

\section{B. Analysis}

In elaborating social experience and social psychology, Mead believes that according to social psychology, we construct group behavior perceived from the behaviors of each individual forming the group; we start from the social entirety of certain complex group activity and where we analyze each individual forming it.

From this view, it is apparent that the group of motorcycle riders violating road markings is an instant group formed of individuals, but the apparent behavior is the behavior of the entire group. The apparent behavior seems to be in disorder, overtaking each other, but with tolerance among them. This group is formed suddenly when there are many motorcycles at the end of an intersection. If only a few motorcycles are there, the group is not formed. The phenomenon is a reality that can be viewed, felt, touched, heard, etc. The reality of 
violation of traffic signs, road markings, and traffic signals appears on the basis of awareness of the riders. This is an awareness of matters through the process of perception and interpretation.

This assumption explains action or behavior as a circulation of conscience and behavior between stimuli and respond produced. Behavior must be studied psychologically and sociologically to see behavior behind the meaning. Meanings we attach to symbols are products of social interaction and represent consensus or agreement on meanings of certain symbols. Then, meaning is created in human interaction. Mead believes that meaning can only appear when the interacted human share interpretation. Meanwhile, Roloff [13] believes that meanings are "social products" or "creation that are formed in and through the defining activities of people as they interact". Then, Roloff [13] finds that there are two steps in the interpretation process. First, people perceive things as possess meanings. Second, it involves processes of selection and study and then transforms meaning in the context of their own. Next, interpretation process heavily depends on a social understanding of a meaning acceptable by concerned culture. In the context of traffic awareness, this justifies the opinions of $[5,6]$ that the factor of drivers understanding plays vital role in decoding traffic signs.

LaRossa and Reitzes [11] opinion on the importance of the self-concept is almost identical to Mead's. They believe that self-concept, apart from related to physical condition, also connected to talent, role, emotional condition, values, skill and social boundary, and intellect. LaRossa and Reitzes [11] add two things, namely individual develops self-concept through interaction with others, and self-concept provides important motive to action and behavior. LaRossa and Reitzes [11] opinion on the relationship between individual and society emphasizes on the relationship between individual freedom and social obstacle. People and group are affected by the socio-cultural process, and social structure is formed by social interaction.

That there are many people doing their business in Jakarta in the afternoon, particularly those come from peripheries, can be witnessed from how tight motor vehicles going to Jakarta in the morning and out of Jakarta in the evening are. The vast number of vehicles on the street prompts people having activities in Jakarta to prefer motorcycle that is considered more practical and effective. A motorcycle can move more freely, given the chance, everywhere with less operational cost and more time-saving compared to private car or public transportation. With the distance between home and workplace or school about 20 - 30 kilometers, motorcycle rider only needs to consume 1 (one) liter of gasoline or about IDR 6,500 using premium.

From brief interviews with motorcycle rider informants, it can be concluded that they use motorcycles to get to the destination sooner since lateness bears consequences to their jobs. The street environment factor also affects the motive of the riders to race. Boredom over crowded streets, clogging, exhaust gas, traffic indiscipline, and the loss of time, energy, and gasoline forces a quick process of perception and interpretation without much consideration. This is due to seeing chances and the factor of habit, ignorance, and others.
Analyzing the action and behavior of motorcycle riders inclined to ignore the messages conveyed by traffic signs and road markings can be conducted employing behaviorist approach. Mead states that stimulus arrived will evoke a respond from people to act. Stimulus received by motorcycle rider is considered as a chance or opportunity to act, not because of coercion or command [8].

From the view above, the author makes a comparison to the action or behavior of the drivers, specifically motorcycle riders, who always seek the opportunity to be at the front line of an instant group they belong to. Stimulation comes from within self and from the outside or environment. Someone will connect the situation he met with the experiences from previous days. Among others, when he is at the most front, he can pass the intersection quickly without being disturbed by other vehicles. Experiences show that whatever he does, although it violates the traffic rules, bears no consequences, except his own safety. There is no risk of getting ticket or fine.

These parts of instant group basically receive the same external stimulation, namely the same traffic sign or light. However, each has his own urge. They count seconds to light changes. Some of them do not have enough patience to wait, so they break through the intersection even when the light has not changed, without regard to their own safety or others. This action then is followed by other riders. Meanwhile, riders from other direction see the light is about to change from yellow to red, but they calculate that there is still enough time to pass. This will end in disorderliness which can lead to clogging.

The author witnessed with his own eyes at the intersection of Jalan Gatot Subroto - M. T. Haryono and Jalan Pasar Minggu - Prof. Dr. Supomo, South Jakarta, how two motorcycle riders crashed with each other. The one from the east saw the red light about to ignite and raced to the west. Meanwhile, the rider from the west heading south (to Pasar Minggu) saw the green light is about to ignite and think he had the opportunity to accelerate forward. The inevitable result was they met halfway at the centre and bumped into each other severely. In the situation, they did not calculate the risk rising from ignoring the message of a traffic light. What is important to them was they saw an opportunity and there was an inner stimulus or urge to go forward.

Perception is an active and creative process in which people interpret things, situations, other people, or circumstances, through several stages until they get an assessment. It begins with sensing through human senses, in particular sight and hearing, provided by stimuli, then passed on to the brain and then interpreted into a perception.

As has been discussed above, Mulyana quotes Sereno and Bodaken, and Pearson and Nelson believe that perception comprised of three phases, namely selection, organization, and interpretation. The selection includes sensation and attention, while the organization is attached to interpretation, which can be defined as put together a stimulant with another stimulant to become a meaningful entirety [10].

Perception is said to be the core of communication and interpretation is the core of perception [17]. Communication happens at the intersection or road is non-verbal communication through symbols, namely traffic signs including traffic lights and road markings. The physical and 
psychological conditions of the motorcycle riders are different to those of car drivers. Motorcycle riders must fully concentrate on the situation around them, face the hot or rainy weather, inhale exhaust gas and think about the condition of their own motorcycle. At the same time, they must think or process external stimuli, select and organize them, and make an interpretation. Thus, when they act according to this perception, it may be incorrect.

Road users, in particular, motorcycle riders and public transportation drivers, also undergo the same process when received external stimuli. They make interpretations, then select the messages received, then decide on taking action. The action or behavior taken can be accurate or not depend on the situation, motive, feeling, value, need, and goal of each person. From the definitions of perception, on the basic, human receive stimuli, then through his sensing he starts to give attention, then interprets it according to each personal background.

Manipulation of the incoming stimulation can also have bad consequences for the riders or drivers since at this stage they must make a correct interpretation, although it must be done on short time since he must concentrate on his driving style, avoid getting accident or touch other vehicles. For instance, the riders or drivers, when percept that there are police officers ahead, and if they violate the rules they will get a ticket, then they will behave politely on the street. However, if they percept oppositely, that there is no police officer or that they will not get a ticket, that they will do as can be seen today.

\section{IV.CONCLUSION}

From the study and analysis above, it can be concluded that (1) Traffic violation and the ignorance of the message of traffic signs is stimulated by internal and external motive and other factors. There is a profit - loss calculation. The internal factor includes the wish to get to the destination sooner, be it a place of activity (office, campus, business, etc.) or home, and disobedience to traffic rules or internal rebellion. External factor includes stimulation of the situation in which they do not want to get trapped in the clogging, see opportunity, and do not fear sanction since there is ignorance or permissive situation; (2) The role and presence of traffic officers at the intersection and on the street are not at optimum level. Although traffic signs are present, there is a scarcity of officers. Meanwhile, the number of vehicles is exploding. Then, the drivers, in particular, motorcycle riders, belong to an instant community, in which they have an unwritten consensus of a feeling of togetherness and concurrently a competition to be the fastest. There is also another consensus among them of consciously violating the rules. The next thing happens is ignorance or permissivism in traffic activity; (3) Road user's perception of symbols is physical perception. Traffic signs are immobile or in-animated objects. Traffic lights only change color from red to yellow to green and vice versa. It means, even if there is a violation of rules, the traffic signs do nothing. They just keep sending messages to other road users. Therefore, motorcycle riders are inclined to ignore the meaning of the signs for conditions such as no sanction given unless there is an inspection. Another factor is faded or blurred traffic signs which go unnoticed. There is also pressure from the environment so that the driving motive beats discipline and obedience.

Some Recommendation are given as follow; (1) Traffic ethics and disciplinary should be constantly socialized through various media, be it high or low line media, to remind and accustom road users to the effort of selfdiscipline; (2) Firm sanction must be implemented to all violation, be it on the street and at the intersection/road crossing, in line with stipulations. The society must be informed beforehand so they will consciously avoid committing violation; (3) Officers must be sent to certain segments at busy hours (peak hours), and they must be consistent to stipulations. Officers must build a positive image, act according to rules, and not giving the impression of framing road users; (4) Traffic signs or road markings must be renewed to appear clearly as order or prohibition messages for road users. Traffic lights must not be installed diagonally so that they will not puzzle road users; (5) CCTV can be installed at every corner of intersection/road crossing, so vehicles violating road markings or traffic signal emitting devices can get fine/ticket billed to their address, or it can be billed at the time of vehicle licenses renewal.

\section{ACKNOWLEDGMENT}

This research is supported by University of Prof. Dr. Moestopo (Beragama), Jakarta, Indonesia.

\section{REFERENCES}

[1] Susantono, Bambang. "Transportation Land Use Dynamics in Metropolitan Jakarta", Berkeley Planning Journal 12 (1) 1998, University of California, Berkeley. 1998.

[2] Maksum, Irfan Ridwan, "Managing Jakarta Megapolis: Quo Vadis?" Makara Sosial Humaniora Vol 13 No 1, July 2009. 13-18, Universitas Indonesia, Depok. 2009.

[3] Nejad, H.M., Seyed, M.H. \& Omid A. "Presentation a Model of Effect of Social Traffic Behavior on Traffic Violation, The Case Study of Tehran Metropolis", International Journal of Applied Science and Technology Vol. 1 No. 4. July 2011. Centre for Promoting Ideas, USA. 2011.

[4] Alhindi, W.A., and Albawardy, F.A. "Drivers Attitudes Towards Red Light Violations Monitoring System”, Life Science Journal, 2013, 10 (10s), 180-187.

[5] Razzak, A. and Tanweer, H. "Motorist Understanding of Traffic Sign: A Study in Dhaka City", Journal of Civil Enginering (IEB), 38 (1) (2010).17-29. 2009.

[6] Zhang, T., and Chan, H.S. "Traffic Sign Comprehension: A Review of Influential Factors and Future Directions for Research", Proceeding of International Multiconference of Engineers and Computer Scientist 2013 Vol II, IMECS 2013, 13-15 March 2013, Hongkong. 2013.

[7] West, R. \& Turner, L.H., Introducing Communication Theory, Analysiss and Application. McGraw-Hill International Edition, Singapore. 2007.

[8] Ritzer, George \& Goodman, Douglas J., Modern Sociology Theory. Sixth Edition, McGraw-Hill, Translated by Kencana Prenada Media Group, Jakarta, Indonesia. 2007.

[9] Mulyana, D. Communication Science An Introduction. PT. Remaja Rosdakarya, Bandung. 2007.

[10] Mulyana, D. Qualitative Research Methodology, New Paradigm of Communication Science and Other Social Sciences. PT. Remaja Rosdakarya, Bandung. 2008.

[11] LaRossa, R. and Reitzes, D.C., 1993. Continuity and change in middle class fatherhood, 1925-1939: The culture-conduct connection. Journal of Marriage and the Family, 55(2), pp.455-465.

[12] Sabatelli, R.M. and Shehan, C.L., 2009. Exchange and resource theories. In Sourcebook of family theories and methods (pp. 385417). Springer US.

[13] Roloff, M.E., 1981. Interpersonal communication: The social exchange approach (Vol. 6). Sage Publications, Inc. 
[14] Kuswarno, Engkus., Method of Phenomenology Communication Research - Concepts, Guidance, and Examples. Widya Padjadjaran, Bandung. 2009.

[15] The Republic of Indonesia, Law Number 22 Year 2009 on Road Traffic and Transportation. Jakarta. 2009.

[16] Ministry of Transportation Land and Railway Research and Development Centre. Master Plan of Jabodetabek Transportation (MPJT), R \& D Body Ministry of Transportation, Jakarta. 2015.

[17] Rakhmat, J. Communication Research Method. Remaja Rosdakarya, Bandung. 2004. 